\title{
Formal evidence-based medicine instruction in Turkish undergraduate medical education: an initial evaluation
}

\author{
Özlem Serpil Çakmakkaya®D
}

\begin{abstract}
Background: Global and national undergraduate medical education accreditation organizations recommend the inclusion of Evidence-Based Medicine (EBM) instructions into the medical schools' curricula. Accordingly, some Turkish medical schools have individually developed and implemented EBM training programs, but there is no data of current programs' effectiveness and students' learning achievements due to the lack of a validated Turkish language EBM assessment tool.

This study evaluates the effect of a newly introduced formal EBM instruction to the curriculum on students' knowledge and skills by using the recently published Turkish adaptation of the Fresno Test.

Methods: The study is an experimental investigation using pre- and post-test evaluations. A five-week EBM course was developed according to Kern's six-step curriculum development approach. A total of 78 students from the third $(n=30)$, fourth $(n=19)$ and fifth $(n=29)$ year of medical school voluntarily consented and were enrolled into the course. Overall, the Cerrahpaşa Medical Faculty had a total of 555, 461, and 400 students enrolled in the third, fourth, and fifth year, respectively.

The program has been evaluated based on students' learning achievements and survey responses.

Results: The students' mean pre-test Fresno Test score improved from $49.9 \pm 18.2$ to $118.9 \pm 26.3$ post-training. The Cohen's effect size was $3.04(95 \% \mathrm{Cl}, 2.6-3.5)$. The overall students' satisfaction score was $8.66 \pm 1.09$ on a 1 to 10 scale.

Conclusions: The program was effective in improving students' knowledge and skills on EBM. We propose to offer the program as an elective course during the third year of the medical school curriculum based on all data obtained during the program evaluation.
\end{abstract}

Keywords: Evidence-Based Medicine, Program development, "Education, Medical", Fresno Test, Program assessment

\section{Background}

Evidence-Based Medicine (EBM) is the conscientious explicit and judicious use of current best evidence in combination with clinical experience in making decisions about the care of individual patients [1]. Practicing EBM requires knowledge and skills. The lack of knowledge

Correspondence: serpilc@istanbul.edu.tr

Department of Medical Education, Istanbul University-Cerrahpaşa, Cerrahpaşa Medical Faculty, 34098 Fatih, Istanbul, Turkey and skills is one important factor that hinders the practice of EBM [2]. Today, national and international educational organizations and boards emphasize that EBM training should be included in the medical schools' curricula. However, no consensus has yet been reached on the most effective training methods or strategies [3]. Educational research studies are not sufficient to draw a clear conclusion, but these studies can help to suggest important principles for developing new EBM training

(c) The Author(s). 2021 Open Access This article is licensed under a Creative Commons Attribution 4.0 International License, which permits use, sharing, adaptation, distribution and reproduction in any medium or format, as long as you give appropriate credit to the original author(s) and the source, provide a link to the Creative Commons licence, and indicate if changes were made. The images or other third party material in this article are included in the article's Creative Commons licence, unless indicated otherwise in a credit line to the material. If material is not included in the article's Creative Commons licence and your intended use is not permitted by statutory regulation or exceeds the permitted use, you will need to obtain permission directly from the copyright holder. To view a copy of this licence, visit http://creativecommons.org/licenses/by/4.0/ The Creative Commons Public Domain Dedication waiver (http://creativecommons.org/publicdomain/zero/1.0/) applies to the data made available in this article, unless otherwise stated in a credit line to the data. 
programs [4]. Based on these suggested principles, the content of the training program should cover the basic steps of EBM, the educational methods should be interactive, student-centered, clinically integrated and the EBM training should be introduced in the pre-clinical years [4-6]. Considering these main principles, medical schools can develop a training program that is in line with their education programs' goals and objectives, the needs of their target groups, and their resources $[3,6]$.

In Turkey, the national accreditation standards for undergraduate medical education recommend that medical schools should include evidence-based medical practices in their program [7]. This standard is a quality development standard, not a basic standard yet, which means that teaching EBM is currently not strictly required. Accordingly, some Turkish medical schools have individually developed and implemented EBM training programs, but other medical schools did not establish such programs. There is no data of current EBM programs' effectiveness and students' learning achievements due to the lack of a validated Turkish language EBM assessment tool; previous studies mostly report students' perspectives $[8,9]$. This study is the first Turkish study that reports students' knowledge and skills in EBM before and after a newly implemented formal instruction using the recently published Turkish adaptation of the Fresno Test [10].

The aim of the study was to evaluate the effect of a new EBM training program on students' knowledge and skills, which was developed based on current literature suggestions and our medical school needs and resources.

\section{Methods}

This study was carried out at Istanbul University - Cerrahpaşa, Cerrahpaşa Medical Faculty (CMF), after it was approved by the CMF ethics committee. All volunteer students gave written informed consent before the pretest and start of the course. The study was designed and conducted in accordance with the principles of the Declaration of Helsinki.

The study is a cross-sectional experimental investigation using pre- and post-test evaluations.

\section{Participants}

CMF has two different programs based on primary teaching language, a Turkish and an English program. Students of both programs were invited to participate in the EBM training. Participants were attending the third, fourth and fifth year of medical school. Undergraduate medical education takes six years in Turkey. The newly developed EBM course was offered to all students in their clinical years except for sixth year students. Most of the students take the residency entry exam at the end of the sixth year, and preparation usually does not allow for additional voluntary coursework. The aim was to teach 25 students from each of the three classes on a voluntary basis. To account for possible dropouts, up to 30 students from each year were allowed. The announcement of the voluntary new EBM program was posted on the web page of the medical school, and an application form was provided.

Students who did not complete one of the pre- or post-tests or who were absent from two or more classes were excluded from the study. A total of 78 students from the third $(n=30)$, fourth $(n=19)$ and fifth $(n=29)$ year of medical school voluntarily consented and were enrolled into the course. Overall, the CMF Turkish Program had a total of 447, 367, and 300 students enrolled in the third, fourth, and fifth year, respectively. The English Program had 108, 94, and 100 students in the same order.

\section{Educators}

Lectures and workshop were given by three faculty members who were experts on EBM and biostatistics.

\section{Intervention}

A five-week EBM course was developed according to Kern's six-step curriculum development approach [11]. The program has been designed around the basic steps of EBM [12].

Problem identification and general needs assessment: As the first step of program development, the World Federation of Medical Education's Global Standards [13] and National Accreditation Standards [7] regarding teaching EBM have been taken into consideration.

Targeted needs assessment: The curriculum of CMF was evaluated. Although there were different lectures on EBM topics in some clerkship programs, there were not any EBM specific programs.

Aims and objectives: The aim of the program was to provide students with the basic knowledge and skills in the field of EBM and to enable students to understand the concept and application of EBM.

Educational Strategies: According to the Khan and Coomarasamy classification, the educational method of the course can be considered as Level IIa; Interactive and classroom based education [14]. We used homework assignments, interactive workshops, and critical appraisal sessions. The program was developed within the framework of pedagogical learning concepts, but it has also been influenced by adult learning theories $[15,16]$. In accordance with adult learning theories, the course was offered as an extracurricular volunteer learning activity without any extrinsic motivational factors. Students signed up for the course by intrinsic motivation (humanistic theories); pre-test questions and test results allowed them to use critical reflection and helped them to be 
aware of knowledge gaps regarding EBM (transformative learning theory).

Course Program: The detailed course program and weekly schedules are explained in Table 1.

Evaluation: The first two steps of the Kirkpatrick Model for the program evaluation were used (Fig. 1) [17].

Kirkpatrick's learning step and students' success were assessed with the Turkish version of the Fresno Test [10]. The original Fresno Test was designed to assess the effectiveness of a comprehensive EBM curriculum at the
University of California, San Francisco's Fresno family practice residency program [18]. The test consists of 12 questions, starting with two clinical scenarios. Short answer questions about the clinical scenarios require the student to formulate a focused clinical question, identify the most appropriate research design to answer the question, show knowledge of database search methods, identify issues important for determining the relevance and validity of research articles, and discuss the magnitude and importance of research findings. The remaining questions, a series of statistical calculations and fill in

Table 1 Program Details

\begin{tabular}{|c|c|c|c|c|}
\hline \multirow[t]{2}{*}{ Week } & \multirow[t]{2}{*}{ Outline } & Objectives & \multirow[t]{2}{*}{ Content } & \multirow[t]{2}{*}{$\begin{array}{l}\text { Educational } \\
\text { Method }\end{array}$} \\
\hline & & $\begin{array}{l}\text { By the end of the session students will be } \\
\text { able to: }\end{array}$ & & \\
\hline 1. & $\begin{array}{l}\text { - Pre-test } \\
\text { - Introduction to EBM } \\
\text { practice } \\
\text { - Formulating focused } \\
\text { clinical questions } \\
\text { using the PICO } \\
\text { formula }\end{array}$ & $\begin{array}{l}\text { - Explain the concept of EBM } \\
\text { - List the components of the PICO formula } \\
\text { - Understand types of the PICO question } \\
\text { - Formulate a focused clinical question } \\
\text { - Value using the most reliable scientific } \\
\text { evidence as well as professional experience } \\
\text { and patient's values together on clinical } \\
\text { decision }\end{array}$ & $\begin{array}{l}\text { - Students were informed about the course } \\
\text { - Pre-test was applied before the main training } \\
\text { started } \\
\text { - An interactive lecture was given about the } \\
\text { concept of EBM and the creation of clinical } \\
\text { questions using the PICO format } \\
\text { - A homework assignment was given at the end of } \\
\text { the lecture }\end{array}$ & $\begin{array}{l}\text { - Interactive } \\
\text { classroom } \\
\text { lecture } \\
\text { - Homework } \\
\text { assignment }\end{array}$ \\
\hline 2 & PubMed Class & $\begin{array}{l}\text { - Explore different databases and understand } \\
\text { their strengths and weaknesses } \\
\text { - Create search strategies by using Boolean } \\
\text { operators (AND, OR, NOT) } \\
\text { - Perform MeSH database search } \\
\text { - Know how to find MeSH terms } \\
\text { - Use PubMed tags and filters }\end{array}$ & $\begin{array}{l}\text { - The workshop was held in a computer lab where } \\
\text { each student could work with an individual } \\
\text { computer } \\
\text { - The training included the use of Boolean } \\
\text { operators, MeSH database search, creating search } \\
\text { strategies, using search filters, creating an NCBI } \\
\text { account and setting e-mail alerts for saved searches }\end{array}$ & Workshop \\
\hline 3 & $\begin{array}{l}\text { Designing Scientific } \\
\text { Research }\end{array}$ & $\begin{array}{l}\text { - Name different types of scientific research } \\
\text { designs } \\
\text { - Explain levels of evidence by using hierarchy } \\
\text { of evidence pyramid } \\
\text { - Explain the concept of randomization } \\
\text { - Explain the importance of allocation } \\
\text { concealment } \\
\text { - Understand the concept of blinding }\end{array}$ & $\begin{array}{l}\text { The course content included introducing different } \\
\text { study designs, randomized controlled trials, cohort } \\
\text { studies, diagnostic and prognostic studies, bias in } \\
\text { scientific research, prevention of bias, and the EBM } \\
\text { pyramid. }\end{array}$ & $\begin{array}{l}\text { Interactive } \\
\text { classroom } \\
\text { lecture }\end{array}$ \\
\hline 4 & Biostatistics & $\begin{array}{l}\text { - List the concepts used in the evaluation of } \\
\text { statistical significance (such as p value, } \\
\text { confidence interval, type I and type II errors) } \\
\text { - Give an example of confidence interval } \\
\text { expressing statistical significance } \\
\text { - Calculate following measures given clinical } \\
\text { scenarios } \\
\text { o Sensitivity } \\
\text { o Specificity } \\
\text { o Positive predictive value } \\
\text { o Negative predictive value } \\
\text { o Probability ratio values } \\
\text { o Absolute risk reduction } \\
\text { o Relative risk reduction } \\
\text { o Numbers Needed to Treat (NNT) }\end{array}$ & $\begin{array}{l}\text { Statistic class was designed to understand the } \\
\text { biostatistical approaches in scientific articles. } \\
\text { Therefore, especially risk calculations, measures of } \\
\text { diagnostic accuracy, Type I and II errors, confidence } \\
\text { intervals, and } p \text { value were discussed. }\end{array}$ & $\begin{array}{l}\text { Interactive } \\
\text { classroom } \\
\text { lecture }\end{array}$ \\
\hline 5 & $\begin{array}{l}\text { - Critical appraisal of } \\
\text { scientific articles } \\
\text { - Post-test } \\
\text { - Students' satisfaction } \\
\text { survey }\end{array}$ & $\begin{array}{l}\text { - Understand the concepts of internal and } \\
\text { external validity of scientific research } \\
\text { - Explain the concept of bias } \\
\text { - List the most common types of bias } \\
\text { - Use the critical appraisal tools }\end{array}$ & $\begin{array}{l}\text { - During the last week, the critical appraisal of } \\
\text { scientific articles was discussed interactively } \\
\text { - The main theme of the training was the evaluation } \\
\text { of the validity and reliability of scientific research } \\
\text { using checklists } \\
\text { - After the completion of the fifth week of } \\
\text { education, the post-test and the student satisfaction } \\
\text { survey were applied }\end{array}$ & $\begin{array}{l}\text { Critical } \\
\text { appraisal } \\
\text { workshop }\end{array}$ \\
\hline
\end{tabular}




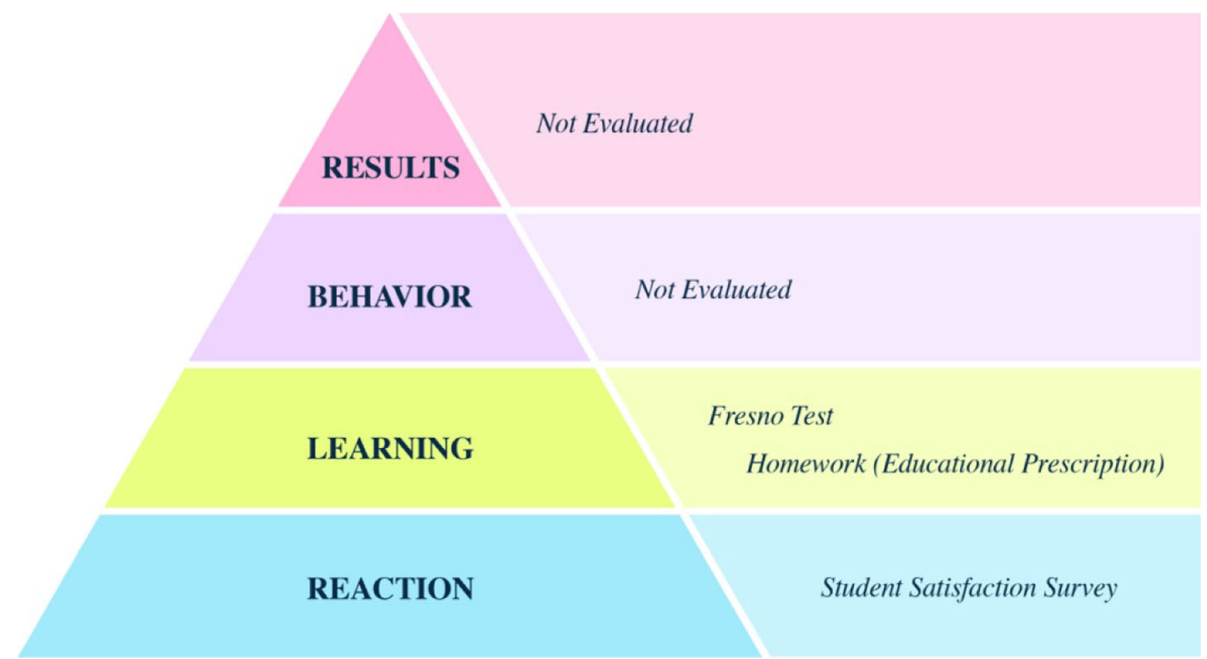

Fig. 1 Evaluation steps and methods of the EBM course according to the Kirkpatrick Model

the blank questions, are independent of these scenarios. The maximum score that can be achieved is 212 . The test is scored by using a standardized system (Grading Rubric) [18]. There was a six-week time period between pre-test and post-test because of a one-week break between the fourth and fifth sessions. Both tests were identical.

Additionally, educational prescriptions were used as homework assignment. Students had to create a focused clinical question using the PICO format, acquire the best evidence, and appraise the evidence related to a specified clinical problem. Every student received feedback for homework.

Students' satisfaction was assessed with a survey. All participants answered a survey that evaluated their satisfaction levels after the post-test application on the day they completed the training program. Evaluation of each weekly class as well as an overall program evaluation was asked for. Satisfaction scores ranged from 1 (not satisfied at all) to 10 (highly satisfied). Additionally, students were asked to report strengths, weaknesses, and opportunities of the program and how well it met their expectations. Also, the students' opinion on which year of medical school would be most appropriate to teach the EBM program was asked.

Program Educators' perspectives and thoughts were collected during regular review meetings and at the end of the course.

A SWOT (Strengths, Weaknesses, Opportunities, Threats) analysis was performed, using the data of the students' survey, Fresno Test scores, and faculties' opinions [19].

Timing of EBM Instruction: To determine which year of medical school is the most appropriate for the EBM program, following factors were taken into consideration:
Comparison of students' pre- and post-test scores between the third, fourth and fifth years of the medical school, students' comments provided by survey, a curriculum analysis, and the number of applications from each class.

\section{Statistical analysis}

The paired samples t-test and the McNemar test to compare pre-test and post-test scores as appropriate, and the Kruskal-Wallis test to compare students' preand post-test scores between the third, fourth and fifth years of the medical school were used.

All data are reported as mean \pm standard deviation (SD), or number (n) and percent (\%).

Statistical significance was accepted at $p<0.05$.

Statistical analysis was performed using STATA SE 14.2 (StataCorp LP, College Station, TX) and SPSS Statistics for Windows, Version 23.0. Armonk, NY: IBM Corp.

\section{Results}

A total of 98 students applied to attend the program: 50 from the third, 19 from the fourth and 29 from the fifth year. Of the third-year students, 30 applications were randomly selected by lot. The number of applications from fourth year students was only 19, likely due to the high intensity of clinical clerkships during that year, and all were accepted. From the fifth year 29 students applied and were accepted. A total of 78 students were accepted and enrolled for the course. Two enrolled fifth year students never started the course. Among the remaining 76 students, four students were excluded from the analysis because three of them did not complete the post-test and one student did not attend two classes (Fig. 2). 
Applied

(98 Students)

20 students were eliminated by lot (3rd year)

\section{Accepted}

(78 Students)

2 students never started the program ( 5 th year)

\section{Took the pre-test \\ and started the \\ course \\ (76 Students)}

3 students did not complete the post-test (5th year)

1 student missed two classes (3rd year)

\section{Took the post-test}

(72 Students)

Fig. 2 Flow-chart of the study participants

Demographic data of the students are presented in Table 2.

\section{Students' learning achievements}

The average test score was $49.9 \pm 18.2$ out of 212 in the Turkish version of Fresno Test prior to participating in the course. The average post training score was $118.9 \pm$

Table 2 Demographic characteristics

\begin{tabular}{|c|c|c|c|c|}
\hline & 3rd Year & 4th Year & 5th Year & Total \\
\hline Number of students & 29 & 19 & 24 & 72 \\
\hline \multicolumn{5}{|l|}{ Program $^{b}$} \\
\hline Turkish & $13(34)$ & $10(26)$ & $15(40)$ & 38 \\
\hline English & $16(47)$ & $9(26.5)$ & $9(26.5)$ & 34 \\
\hline $\mathrm{Age}^{\mathrm{a}}$ & $20,9 \pm 1,04$ & $21,8 \pm 0,85$ & $22,38 \pm 0,49$ & $21,6 \pm 1,05$ \\
\hline \multicolumn{5}{|l|}{ Gender $^{\mathrm{b}}$} \\
\hline Female & $15(39)$ & $11(28)$ & $13(33)$ & 39 \\
\hline Male & $14(42)$ & $8(25)$ & $11(33)$ & 33 \\
\hline
\end{tabular}

${ }^{\mathrm{a}}$ Mean \pm SD. ${ }^{\mathrm{b}}$ Number (\%)
26.3 with a change of 69 points (95\% CI, 63.9-74.2) (Fig. 3). The Cohen's effect size was 3.04 (95\% CI, 2.63.5) indicating a very large change in scores.

Pre-test scores ranged from 9 to 90 , and post-test scores from 63 to 180 . The smallest individual increase in score from pre-test to post-test was 20 , and the largest was 118. No student's score declined from pre-test to post-test.

A post-hoc comparison of test scores between Turkish and English Program students was performed (Table 3). Pre-test scores of Turkish Program students was $46.7 \pm$ 19.1 and $53.2 \pm 16.9$ for English Program students $(p=$ 0.154). Post-test scores of Turkish Program students $(109.4 \pm 26.4)$ were lower than those of the English Program $(129.5 \pm 21.9)(p=0.001)$ (Fig. 4).

When the Fresno Test results were analyzed on a question basis, there was a significant increase for all questions, except "diagnostic study design" question. We found the highest score increase for the "biomedical databases and developing search strategies" question. 


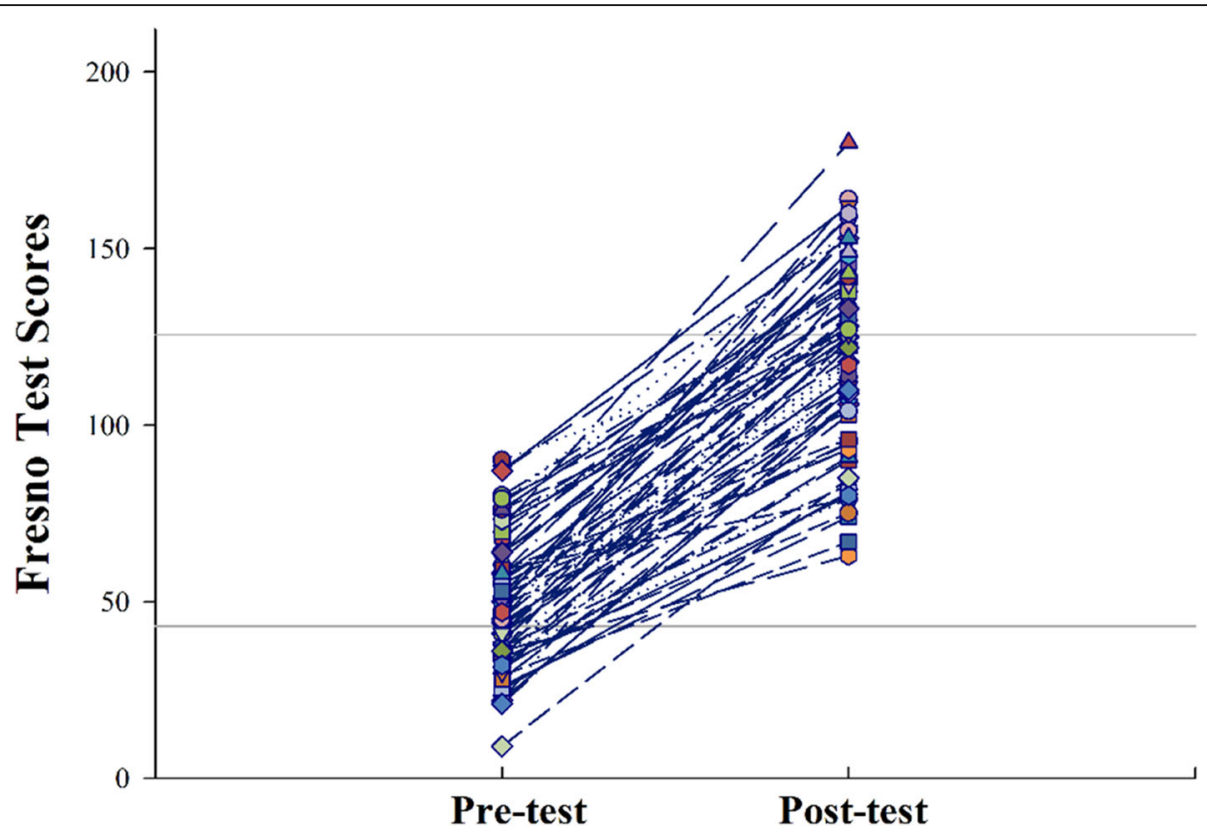

Fig. 3 Mean pre- and post-test scores of all students $(n=72)$

\section{Students' satisfaction}

The overall satisfaction level of the students was $8.66 \pm$ 1.09 out of 10. Students stated that the EBM course has met their expectations. No student commented negatively. The main aspects of the program from students' perspective are summarized below.

\section{Strengths of the program}

- The program is structured to support scientific thinking rather than overloading the factual knowledge

- Increases the ability to follow scientific literature and to support continuous learning processes

- PubMed workshop was one of the strongest parts of the program

- Faculty members, who are the experts on the field of EBM
- Interactive teaching methods

- Getting prompt feedback on homework assignments

- Treats offered before and between classes

- Emailing system

\section{Weaknesses of the program}

- Short duration of the course

- Since the classes started after their daily school program students felt tired

\section{Developmental aspects and recommendations for the program}

- Extension of course duration

- Integrating with clinical practice

- Increasing the number of assignments

Table 3 Fresno Test scores of Turkish and English Program students

\begin{tabular}{|c|c|c|c|c|}
\hline \multirow[t]{2}{*}{ Program } & \multicolumn{2}{|l|}{ Fresno Test scores $^{a}$} & \multirow[t]{2}{*}{ Effect size ${ }^{b}$} & \multirow[t]{2}{*}{$p$} \\
\hline & Pre-test & Post-test & & \\
\hline $\begin{array}{l}\text { Turkish } \\
\text { Program } \\
(\mathrm{n}=38)\end{array}$ & $46.7 \pm 19.1$ & 109.4. \pm 26.4 & $62.7(55.7-69.2)$ & $<0.0001$ \\
\hline $\begin{array}{l}\text { English } \\
\text { Program } \\
(n=34)\end{array}$ & $53.2 \pm 16.9$ & 129.5. \pm 21.9 & $76.4(69.22-83.54)$ & $<0.0001$ \\
\hline$p$ & $\begin{array}{l}0.54 \text { (Pre-test comparison of two } \\
\text { programs) }\end{array}$ & $\begin{array}{l}0.001 \text { (Post-test comparison of two } \\
\text { programs) }\end{array}$ & $\begin{array}{l}0.006 \text { (Effect size comparison of two } \\
\text { programs) }\end{array}$ & \\
\hline
\end{tabular}

${ }^{\mathrm{a}}$ Mean \pm SD, ${ }^{\mathrm{b}}$ Effect size (Cl \%95) 
course in the third year of the medical school was decided based on general evaluation results.

EBM can be thought in many different ways during the undergraduate medical education [3]. Despite the diversity of educational methods, the quantity and quality of the evidence to decide which is the most effective EBM teaching method is poor [4]. Systematic reviews have not identified a preferred method [22, 23]. Hatala and Guyatt stated that our knowledge about the outcomes of evidence-based curricula relies on observational data. Therefore, medical schools are recommended to develop local training programs according to the needs of their learners, program aims and objectives, and schools' resources. Additionally, curricula should be developed around the main steps of EBM [12]. When we designed the EBM training program, we decided that the first three steps of EBM, "ask", "search" and "appraise", are best taught as a classroom-based EBM training. The other two steps, "application" and "evaluation", are better addressed in clinical settings during bedside teaching [16]. Therefore, our course was designed to cover the first three steps of EBM. A longitudinal clinically integrated curriculum to cover the remaining steps of EBM is currently in planning.

Our EBM course is the first EBM program in Turkey that used a validated and internationally accepted EBM assessment tool, the Fresno Test [18]. This allowed us to compare the effectiveness of our course with other similar EBM programs in the world. The Fresno Test was first applied to family medicine residents and specialists during the development phase. While residents achieved an average of 95.5 points from the test, experts received 147.5 points [18]. In a multicenter study evaluating the evidence-based medical knowledge levels of medical school students in the United States, the mean score was found to be 102 for allopathic schools [24]. A study from Jordan showed that fifth-year medical students' pre-test scores were 26.7 out of 200 and 119.5 for the post-test after a 2-week short course. They slightly modified the scoring system of the Fresno Test from 212 to a 200 total score [25]. In a Spanish study, residents' Fresno Test scores increased from 63.9 to 111.6 after an EBM course [26]. Our students have not been exposed to any structured EBM training before our newly developed program which explains their low pre-test scores. The improvement of Fresno Test scores is relevant and consistent with the other international studies [25-27].

On detailed review of pre- and post-test scores for each question, we identified areas of limited improvement of student scores. This was especially the case for biostatics topics. This information allowed us to refine the course. For future courses, we decided to allocate more time for statistical lectures, and to add interactive sessions that allow students to perform more calculations and interpretations of statistical analyses.

Although it was not our hypothesis, we found that there was a significant difference between Turkish and English Program students' post-test scores. While pretest scores were comparable, English Program students achieved higher post-test scores. We cannot explain this interesting observation with our study data. But we aim to follow up with future studies.

We suggest including EBM training as an elective course in the third year of the medical school for several reasons. The high number of course applications from third year students (50 applications) was a strong indicator of interest. In addition, we considered the results of the student satisfaction surveys and faculty evaluation. Moreover, we believe that the early introduction of EBM provides benefits. Although there is no strong evidence on the most effective time to start EBM training [3], a pre-clinical implementation might provide educators an extended timeframe to teach longitudinal programs rather than a single innovation. Additionally, early exposure to EBM provides an increase of the students' self-efficacy in their ability to practice EBM [20]. Previous research also suggested that the introduction of EBM in preclinical years increases the students' understanding of the conduct of medical research and that EBM is a necessary foundation to develop clinical skills [21].

This study has limitations. The EBM course was an extra-curricular activity that was carried out over a limited time. Student achievements, early knowledge and skills acquisitions are evaluated at the end of the program. Long-term results of education such as behavioral change or effect on health care were not investigated in the study. Therefore, the sixth step of Kern's framework for curriculum development (Evaluating the effectiveness of the curriculum) was not completed. In addition, the program was designed to cover the first three steps of EBM only. We are planning to integrate the fourth and fifth step with clinical bedside teaching. However, this was out of the scope of the current study. In addition, the timing of the course after students' usual daily program might have affected students' ability to concentrate and learn. We did not use the exam scores for pass or fail decisions, and the results did not affect students' medical school scores. The training was separate from their schoolwork. Therefore, the exam scores obtained with the Fresno Test were only depended on the students' interest and their self-direction without any external motivation. If this course was mandatory, results might have been different. 


\section{Conclusions}

Evidence-based practice is one of the essential elements for improving the quality of health services, reducing healthcare costs and preventing medical errors [28]. One of the responsibilities of medical schools is to graduate physicians who have reached the necessary qualifications in this field by including EBM programs in their curriculums. CMF's EBM program can serve as an example of an effective training for medical schools that have not yet included EBM education into their curriculum. The reported Fresno Test results might allow to compare the students' achievements with other national and international programs.

\section{Author's contributions}

Dr. Özlem S. Çakmakkaya; Conceptualization, Data curation, Formal analysis, Investigation, Methodology, Project administration, Resources, Statistics, Writing and reviewing - original draft. The author(s) read and approved the final manuscript.

\section{Author' information}

Assoc. Prof. Özlem Serpil Çakmakkaya, MD, PhD: Istanbul UniversityCerrahpaşa, Cerrahpaşa Medical Faculty, Department of Medical Education, Istanbul, Turkey.

\section{Funding}

No funds have been received for this study.

\section{Availability of data and materials}

The datasets analyzed during the current study are available from the corresponding author on reasonable request.

\section{Declarations}

Ethics approval and consent to participate

Ethics Committee of the Cerrahpaşa Medical Faculty approved the study (Number: 83045809/604.01/02-264673). All volunteer students gave written informed consent before the pre-test and start of the course. The study was designed and conducted in accordance with the principles of the Declaration of Helsinki.

\section{Consent for publication}

Not Applicable.

\section{Competing interests}

Author declares no financial conflicts of interest related to this paper.

Received: 16 January 2021 Accepted: 11 August 2021

Published online: 19 August 2021

\section{References}

1. Sackett DL, Rosenberg WM, Gray JA, Haynes RB, Richardson WS. Evidence based medicine: what it is and what it isn't. BMJ. 1996;312(7023):71-2. https://doi.org/10.1136/bmj.312.7023.71.

2. Van Dijk N, Hooft L, Wieringa-de Waard M. What are the barriers to residents' practicing evidence-based medicine? A systematic review. Acad Med. 2010;85(7):1163-70. https://doi.org/10.1097/ACM.0b013e318 d4152f.

3. Maggio LA, Tannery NH, Chen HC, ten Cate O, O'Brien B. Evidence-based medicine training in undergraduate medical education: a review and critique of the literature published 2006-2011. Acad Med. 2013;88(7):1022-8. https://doi.org/10.1097/ACM.0b013e3182951959.

4. Hatala R, Guyatt G. Evaluating the teaching of evidence-based medicine JAMA. 2002;288(9):1110-2. https://doi.org/10.1001/jama.288.9.1110.

5. Tilson JK, Kaplan SL, Harris JL, Hutchinson A, Ilic D, Niederman R, et al. Sicily statement on classification and development of evidence-based practice learning assessment tools. BMC Med Educ. 2011;11(1):78. https://doi.org/1 $0.1186 / 1472-6920-11-78$

6. Maggio LA. Educating physicians in evidence based medicine: current practices and curricular strategies. Perspect Med Educ. 2016;5(6):358-61. https://doi.org/10.1007/s40037-016-0301-5.

7. TEPDAD. Curriculum structure and content. In: National Undergraduate Medical Education Standards; 2021. http://tepdad.org.tr/en/documents. Accessed 08 May 2021.

8. Agadayi E, Egilmez R, Altun A. Evidence-based medicine approaches of students in a medical school. Tıp Eğitimi Dünyası. 2020;19(59):86-96. https:// doi.org/10.25282/ted.820562

9. Elçin M, Turan S, Odabaşı O, Sayek I. Development and evaluation of the evidence-based medicine program in surgery: a spiral approach. Med Educ Online. 2014;19(1):24269. https://doi.org/10.3402/ meo.v19.24269.

10. Cakmakkaya OS, Bati AH, Kolodzie K. Cross-cultural adaptation of the Fresno test for Turkish language. PLoS One. 2021;16(1):e0245195. https://doi.org/1 0.1371/journal.pone.0245195

11. Kern DE, Patricia AT, Mark TH, editors. Curriculum development for medical education: a six-step approach. 2nd ed. Baltimore: JHU Press; 1998.

12. Dawes M, Summerskill W, Glasziou P, Cartabellotta A, Martin J, Hopayian K, et al. Sicily statement on evidence-based practice. BMC Med Educ. 2005;5(1): 1. https://doi.org/10.1186/1472-6920-5-1.

13. WFME. Curriculum. In: Basic medical education WFME global standards for quality improvement. The 2020 revision; 2020. https://wfme.org/wpcontent/uploads/2020/12/WFME-BME-Standards-2020-1.pdf. Accessed 08 May 2021.

14. Khan KS, Coomarasamy A. A hierarchy of effective teaching and learning to acquire competence in evidenced-based medicine. BMC Med Educ. 2006; 6(1):59. https://doi.org/10.1186/1472-6920-6-59.

15. Das K, Malick S, Khan KS. Tips for teaching evidence-based medicine in a clinical setting: lessons from adult learning theory. Part one J R Soc Med. 2008;101(10):493-500. https://doi.org/10.1258/jrsm.2008. 080712

16. Malick S, Das K, Khan KS. Tips for teaching evidence-based medicine in a clinical setting: lessons from adult learning theory. Part two J R Soc Med. 2008;101(11):536-43. https://doi.org/10.1258/jrsm.2008.080713.

17. Kirkpatrick D, Kirkpatrick J. Evaluating training programs: the four levels: Berrett-Koehler Publishers; 2006.

18. Ramos KD, Schafer S, Tracz SM. Validation of the Fresno test of competence in evidence based medicine. BMJ. 2003;326(7384):319-21. https://doi.org/1 $0.1136 / \mathrm{bmj} .326 .7384 .319$

19. Teoli D, An J. SWOT analysis. In: StatPearls [internet]: StatPearls Publishing; 2019.

20. Nieman LZ, Cheng L, Foxhall LE. Teaching first-year medical students to apply evidence-based practices to patient care. Fam Med. 2009;41(5): 332-6.

21. Acharya Y, Rao MR, Arja S. Evidence-based medicine in pre-clinical years: a study of early introduction and usefulness. J Adv Med Educ Professionalism. 2017:5(3):95-100.

22. Ahmadi S-F, Baradaran HR, Ahmadi E. Effectiveness of teaching evidencebased medicine to undergraduate medical students: a BEME systematic review. Med Teach. 2015;37(1):21-30. https://doi.org/10.3109/0142159X.2014 971724.

23. Ilic D, Maloney S. Methods of teaching medical trainees evidence-based medicine: a systematic review. Med Educ. 2014;48(2):124-35. https://doi. org/10.1111/medu.12288.

24. Smith AB, Semler L, Rehman EA, Haddad ZG, Ahmadzadeh KL, Crellin SJ, et al. A cross-sectional study of medical student knowledge of evidencebased medicine as measured by the Fresno test of evidence-based medicine. J Emerg Med. 2016;50(5):759-64. https://doi.org/10.1016/j. jemermed.2016.02.006.

25. Barghouti FF, Yassein NA, Jaber RM, Khader NJ, Shokhaibi SA, Almohtaseb A, et al. Short course in evidence-based medicine improves knowledge and skills of undergraduate medical students: a before-andafter study. Teach Learn Med. 2013;25(3):191-4. https://doi.org/10.1080/1 0401334.2013.797348

26. Argimon-Pallàs JM, Flores-Mateo G, Jiménez-Villa J, Pujol-Ribera E. Psychometric properties of a test in evidence based practice: the Spanish version of the Fresno test. BMC Med Educ. 2010;10(1):45. https://doi.org/1 $0.1186 / 1472-6920-10-45$ 
27. West CP, Jaeger TM, McDonald FS. Extended evaluation of a longitudina medical school evidence-based medicine curriculum. J Gen Intern Med. 2011;26(6):611-5. https://doi.org/10.1007/s11606-011-1642-8.

28. Naik VA, Kotur P, Goudar SS. Evidence based medicine and its impact on medical education. Indian J Anaesth. 2002;46(2):96-103.

\section{Publisher's Note}

Springer Nature remains neutral with regard to jurisdictional claims in published maps and institutional affiliations.

Ready to submit your research? Choose BMC and benefit from:

- fast, convenient online submission

- thorough peer review by experienced researchers in your field

- rapid publication on acceptance

- support for research data, including large and complex data types

- gold Open Access which fosters wider collaboration and increased citations

- maximum visibility for your research: over $100 \mathrm{M}$ website views per year

At BMC, research is always in progress.

Learn more biomedcentral.com/submissions 